donated $\$ 5,000,000$ of his fortune with this as a rationale. It was characteristic of the type.

Ellsworth's gifts to Iowa Falls seem to have originated more from the natural, spontaneous expression of a genuinely generous man. Making the most of his energies and abilities, he left his mark upon a portion of Iowa to the benefit of his fellow citizens. This is the real measure of his success.

\title{
Mormon Girl Stopped Indian Attack
}

The diary of Captain Wallace, commander of a contingent of the Mormon trek across Iowa, tells of an attack upon one train by Cheyenne Indians on the plains west of Omaha. Accompanying the party were the two daughters of the man responsible for the Mormon tabernacle at Bethlehem, a former Missouri river town and the last source of supplies before beginning the long trek across the plains to Salt Lake in Utah.

One of the two girls played the guitar and the other sang, and both had learned the heel and toe dance of the Pottawattamie Indians. When the Cheyennes withdrew for a council preparatory to renewing the attack, Mary, the oldest girl, picked up her guitar and strolled leisurely across the prairie toward them strumming the guitar and doing her heel and toe dance. The Indians watched in astonishment and then began to dismount and join in the dance. The rhythm of the music got into their feet as the dancing went on for some time. Finally the Indians shook hands, remounted and rode off north along the the Loup River.-O. J. Pruitt, former curator of the Pottawattamie County Historical Society. 
Copyright of Annals of Iowa is the property of State of Iowa, by \& through the State Historical Society of Iowa and its content may not be copied or emailed to multiple sites or posted to a listserv without the copyright holder's express written permission. However, users may print, download, or email articles for individual use. 